\title{
Circadian Regulation of Glutamate Transporters
}

\author{
Donaji Chi-Castañeda and Arturo Ortega* \\ Laboratorio de Neurotoxicología, Departamento de Toxicología, Centro de Investigación y de Estudios Avanzados del \\ Instituto Politécnico Nacional, Mexico City, Mexico
}

L-glutamate is the major excitatory amino acid in the mammalian central nervous system (CNS). This neurotransmitter is essential for higher brain functions such as learning, cognition and memory. A tight regulation of extra-synaptic glutamate levels is needed to prevent a neurotoxic insult. Glutamate removal from the synaptic cleft is carried out by a family of sodium-dependent high-affinity transporters, collectively known as excitatory amino acid transporters. Dysfunction of glutamate transporters is generally involved in acute neuronal injury and neurodegenerative diseases, so characterizing and understanding the mechanisms that lead to the development of these disorders is an important goal in the design of novel treatments for the neurodegenerative diseases. Increasing evidence indicates glutamate transporters are controlled by the circadian system in direct and indirect manners, so in this contribution we focus on the mechanisms of circadian regulation (transcriptional, translational, post-translational and

OPEN ACCESS

Edited by:

Pierrette Gaudreau, Université de Montréal, Canada

Reviewed by:

Fiorenzo Conti, Università Politecnica delle Marche,

Italy

Alexander A. Mongin, Albany Medical College, United States

*Correspondence: Arturo Ortega arortega@cinvestav.mx

Specialty section:

This article was submitted to Neuroendocrine Science, a section of the journal Frontiers in Endocrinology

Received: 09 February 2018 Accepted: 05 June 2018

Published: 21 June 2018

Citation:

Chi-Castañeda D and Ortega A (2018) Circadian Regulation of Glutamate Transporters.

Front. Endocrinol. 9:340.

doi: 10.3389/fendo.2018.00340 post-transcriptional regulation) of glutamate transport in neuronal and glial cells, and their consequence in brain function.

Keywords: circadian rhythms, clock genes, EAATs, glutamate transporters, neurodegenerative disorders

\section{CIRCADIAN BIOLOGICAL CLOCK}

Life has adapted to 24-h rhythms, better known as circadian rhythms (1). Consequently, a large number of organisms have circadian clocks that anticipate daytime and establish endogenous 24h rhythms, which organize their physiology and behavior $(2,3)$. These endogenous rhythms are synchronized with the environment through external signals, the so-called zeitgebers ("time giver" in German), being the light the principal time cue (4).

Intracellularly, the mechanisms involved in circadian regulation are transcription-translation feedback loops of a group of genes denominated clock genes (5-7). In mammals, Brain muscle arnt-like 1 (BMAL1) and Circadian locomotor output cycles kaput (CLOCK) complexes control the periodic expression of Cryptochrome 1 and 2 (Cry1 and 2), and Period 1 and 2 (Per1 and 2), whose protein products inhibit BMAL1 and CLOCK, as well as their own transcription (58). These circadian transcription factors regulate thousands of clock-controlled genes, which orchestrate diverse physiological, metabolic and behavioral functions, resulting in a synchronized organism (3). Most tissues and cell types in the body possess a molecular clock (peripheral clocks) synchronized by the principal pacemaker located in the suprachiasmatic nucleus (SCN) of the anterior hypothalamus $(2,3,9)$. Approximately, around $2-30 \%$ of each tissue's transcriptome is rhythmically synthesized $(10,11)$.

In mammals, the SCN receives direct photic input from photosensitive retinal ganglion cells via the retinohypothalamic tract $(\mathrm{RTH})(12,13)$. This tract mainly uses glutamate (Glu) as its neurotransmitter; however, pituitary adenylate cyclase-activating peptide (PACAP) and substance 
$\mathrm{P}$ are two peptide co-transmitters that also participate in retino-hypothalamic transmission (14-16). Interestingly, it has been shown that both of these co-transmitters regulate Glu neurotransmission, although the mechanism by which it is carried out remains unknown $(15,17-19)$. In vivo and in vitro studies have identified both metabotropic and ionotropic Glu receptors in the SCN (20-22), although it has been demonstrated that specific distribution and abundance of each Glu receptor subunit differs in this structure resulting in different effects of Glu on SCN neurons (21).

\section{GLUTAMATE}

Glutamate (Glu), the main excitatory neurotransmitter in the mammalian central nervous system (CNS), activates two subtypes of Glu receptors: ionotropic (iGluRs) and metabotropic (mGluRs) (23-25). The first group refers to a family of ligand-gated ion channels that have been classified by means of their pharmacological properties into: $\mathrm{N}$-methyl-D-aspartate (NMDA), and $\alpha$-amino-3-hydroxy5-methyl-4-isoxazolepropionate (AMPA) and kainate (KA) receptors (24). The second subtype of Glu receptors belongs to class C of G-protein-coupled receptors, and its classification is based on the homology of their sequences, pharmacology, and signal transduction mechanisms $(23,25)$. It includes group I (mGluR1 and mGluR5), group II (mGluR2 and mGluR3) and group III (mGluR4, mGluR6, mGluR7, and mGluR8) $(23,25)$. Both subtypes of Glu receptors are widely expressed on pre- and post-synaptic terminals as well as on astrocytes that surround synapses $(23,26,27)$.

Glu concentration in the synaptic cleft is in the low millimolar range $(28,29)$. However, after periods of intense glutamatergic activity, an excessive extracellular Glu concentration leads to an overstimulation of Glu receptors resulting in neuronal death, a phenomenon known as excitotoxicity, which is involved in neurodegenerative diseases $(26,30)$. In this context, Glu uptake from the extracellular space plays an essential role in the prevention of excitotoxic insults (28). A family of $\mathrm{Na}^{+}$dependent high affinity Glu transporters carries out the Glu removal from the synaptic space. The excitatory amino acid transporters (EAATs) comprise five different Glu transporters: Glu/aspartate transporter (GLAST), Glu transporter 1 (GLT1), excitatory amino acid carrier 1 (EAAC1), excitatory amino acid transporter 4 (EAAT4), and excitatory amino acid transporter 5 (EAAT5) or EAAT 1-5 according to rodent and human nomenclature, respectively $(28,31-36)$. These transporters display a 50-60\% amino acid sequence similarity, although different pharmacological and molecular properties, structure, and expression patterns are present for each subtype $(28,37)$. Within the CNS, Glu transporters have differential cell expression (glial or neuronal) $(31,36,38-40)$. GLAST and GLT1 are found predominantly in the astrocytic plasma membrane (3840), whereas EAAC1/EAAT4/EAAT5 are neuronal transporters mainly localized in hippocampal neurons, Purkinje cells, and rod photoreceptor and bipolar cells of the retina, respectively $(31,35$, $36,38,41)$. However, GLT1 expression in neurons $(28,42-44)$, as well as EAAC1 and EAAT4 immunoreactivity in cortical and spinal cord astrocytes have also been reported $(45,46)$. GLAST and GLT1 carry out $\sim 80-90 \%$ of the Glu uptake in the brain (28), and decreased expression and/or malfunction of these Glu transporters are related to several neurodegenerative disorders like Parkinson's, Huntington's and Alzheimer's diseases (47-49).

\section{GENERAL CHARACTERISTICS OF GLUTAMATE TRANSPORTERS IN NEURODEGENERATIVE DISEASES}

Through an antisense approach, it has been demonstrated that Glu transporters malfunction is involved in neurodegeneration in normal animals (47). Subsequently, Tanaka and colleagues reported, in mice lacking GLT1, a decrease of transport activity, lethal seizures and increased susceptibility to neurotoxicity (48). Years later, several research groups have demonstrated the role of Glu transporters in various neurodegenerative diseases. For example, Alzheimer's disease (AD) patients and animal models display a dramatic decrease in Glu transporters protein expression and in Glu uptake that is not correlated to its mRNA levels, demonstrating that other levels of regulation are present (50-54). In addition, Scott and coworkers described that GLT1 mRNA alternative splicing controls Glu uptake both in disease and in normal conditions (55). Moreover, glial Glu transporters have aberrant expression in distinct types of neurons $(56,57)$.

In the case of Parkinson's disease (PD), as with $\mathrm{AD}$, there is also a decrease in Glu uptake; in PD, Glu transporters have an unusual trafficking between membrane and cytoplasm leading a decrease in Glu transporters at the plasma membrane (58). This phenomena relies in Glu transporters' ubiquitination by the E3 ubiquitin ligase Nedd4-2 (neuronal precursor cell expressed developmentally down-regulated 4-2) (58).

Likewise, Glu transporters have a critical role in Huntington's disease (HD), in which the expression of these transporters is diminished, the symptoms of HD worsen (59). In this sense, it has been demonstrated that aberrant huntingtin reduces GLT1 activity, either by dysfunction of the transporter itself or a transcriptional down-regulation, aggravating excitotoxicity (59, 60).

It is well-known that Glu transporters are regulated at different levels, at the transcriptional translational and post translational levels through modifications of transporter protein, as well as by the transporter targeting and trafficking (61-64). Nevertheless, there is compelling evidence demonstrating that Glu transporters are regulated in a circadian fashion.

\section{CIRCADIAN REGULATION OF GLUTAMATE TRANSPORTERS}

\section{Transcriptional, Translational, and Post-translational Regulation}

Until today, it has been demonstrated that in SCN both Glast mRNA and protein levels present a diurnal rhythm in $12 / 12 \mathrm{~h}$ light-dark conditions (65). According to these results, it has been proven that in the Per 2 mutant mice, GLAST protein is 
arrhythmic, highlighting the presence of a circadian regulation (65). Subsequently, using a cortical astrocytes culture from Npas2 and Clock mutant mice, it was reported a decrease in Glast mRNA and protein levels, implying that glial Glu uptake is modulated via clock genes expression: Per2, Clock, and Npas2 $(66,67)$. CLOCK and NPAS2 proteins are involved in Glast transcription or in Glast mRNA translation and/or stability (28), while PER2 modulates GLAST and by these means Glu uptake. In this sense, modifications in NPAS2 and/or CLOCK diminish PER2 levels and Glu uptake (66). More recently, it has been reported that glial Glu uptake within the SCN is modulated in a diurnal fashion (high levels of uptake during the light phase) but it does not exhibit circadian fluctuations (68). Leone and colleagues also report that Glu uptake activity does not change in constant darkness (68). It is important to mention that the possibility that Glu uptake is regulated by circadian clock in vivo cannot be ruled out. In line with these results, another research group also reported that Glu uptake in SCN is increased during the circadian day (22). Brancaccio and coworkers demonstrated that astrocytes modulate circadian timekeeping in SCN through glutamatergic signaling, and identified the presence of self-sustained circadian oscillations of Glu extracellular levels (22). The authors suggest that, in the light phase, Glu uptake is mediated by EAATs, including GLAST, GLT-1, and EAAC1 (22). These results could indicate that both Glu release and uptake are regulated in a circadian fashion.

It is reasonable to suggest that when there is a lack of GLAST transporter, compensation via upregulation of GLT1 is favored (65). For instance, in the Per2 mutant mice it has been determined a shift in GLT1 protein maximal expression, from zeitgeber time 6 (ZT6, in control mice) to ZT18 (65), indicating that GLT1 protein is regulated by circadian clock. It is important to mention that shift in maximal expression of the GLT1 transporter correlates with ZT in which there is a downregulation of GLAST (65), suggesting that total uptake of Glu could be modulated by clock.

Through the use of in situ hybridization techniques in SCN, supraoptic nuclei, cingulate cortex and reticular thalamus of rats in constant darkness, it was found that Eaac1 mRNA expression was rhythmic only in the SCN (69). Circadian expression of this transporter is associated with GABAergic activity regulation in the SCN, due an increased demand of GABA synthesis and release, immediately preceded by an increase in Eaac1 mRNA expression (69). Increase in the expression of this transporter contributes to the neuronal clearance of Glu, which in fact is a precursor of GABA. Within the SCN, $95 \%$ of neurons are GABAergic (70), and together with astrocytes regulate circadian timekeeping through glutamatergic signaling (22), suggesting an important role of Glu transporters in the internal timekeeping system. In contrast, Kinoshita and colleagues could not find any a circadian-mediated Eaac1 mRNA expression neither in serumshocked SH-SY5Y cells and mouse mesencephalon by qRTPCR (71). Taking together, these results suggest that temporal changes in Eaac1 mRNA might be controlled by circadian clock in a tissue-dependent fashion. In addition, Kinoshita and collaborators also described that EAAC1 protein expression exhibits a diurnal variation in a $12 / 12 \mathrm{~h}$ light/dark cycle in mouse mesencephalon (71).

\section{Post-transcriptional Regulation (Circadian MicroRNAs)}

In recent years, the proposal for a novel circadian regulatory system has been gaining ground. MicroRNAs (miRNAs) are a good example of a system that can rapidly respond to external stimuli since it is activated without changes in transcription and/or translation (71). In this context, miRNAs have revealed to be a key factor in the regulation of several circadian components (72-75). It has also been proved that peripheral oscillators exert circadian regulation over miRNAs expression (73-78). Increasing evidence indicates that miRNAs controlled by the circadian clock, regulate Glu transporters. Thus, miRNA-124 increases GLAST expression (79), while miRNA-142-3p and miRNA-155$5 p$ decrease it $(80,81)$. Moreover, it has been demonstrated that miRNA-124 and miRNA-181a positively regulate GLT1 (82, 83), while miRNA-107 inhibits GLT1 expression (84). Specifically, EAAC1 rhythm is negatively controlled by miRNA96-5p (71), miRNA-26a-5p (85) and miRNA-101b (86). This former miRNA also negatively regulates to EAAC1 protein (86). However, no evidence shows that miRNAs can target EAAT4 and EAAT5.

\section{FUTURE DIRECTIONS}

In the last two decades, several research groups have examined the different signaling pathways that modulate glial Glu transporters expression (GLAST and GLT1). Scarce information about EAAC1, EAAT4, and EAAT5 transporters is available. Particularly, EAAC1 has a much less evolutionarily conserved sequence in the $5^{\prime}$ noncoding region compared to GLAST and GLT-1, hindering the identification of cis- and transelements involved in its transcriptional regulation. Specifically, the circadian regulation of Glu transporters is an emerging theme that promises to be an indispensable tool in the preventing and/or treatment of diseases related to alterations in glutamatergic system. Future research should be directed to study of molecular mechanisms involved in circadian modulation of these transporters.

\section{CONCLUSION}

Optimal functioning and precise regulation of Glu removal from the synaptic cleft is critical to prevent an excitotoxic insult and thus avoid several neurodegenerative pathologies. To date, compelling evidence suggests that Glu transporters could be regulated in a circadian fashion (Figure 1). It is clear that desynchronization or aberrant functioning of circadian system results in significant health consequences. In this sense, disruptions in the circadian regulation of Glu transporters is likely to be involved in neurological disorders like Parkinson, Huntington and Alzheimer diseases. Therefore, a better understanding of the molecular mechanisms that participate in the circadian regulation of EAATs might prove important for the proper development of therapeutic strategies aimed to prevent and/or treat pathologies related to excitotoxicity. 


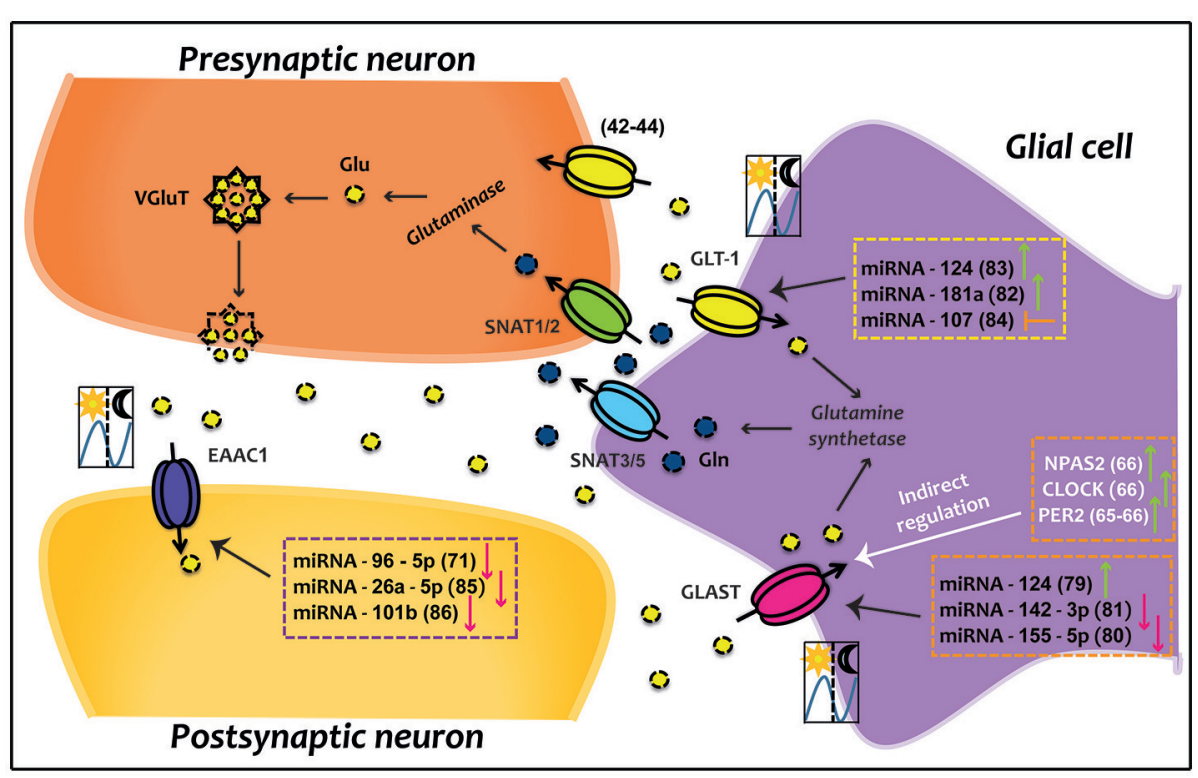

FIGURE 1 | Direct and indirect circadian regulation of EAATs. Glutamatergic synapse which is composed of presynaptic neuron, postsynaptic neuron and glial cell compartment are represented. Some clock genes indirectly up-regulate GLAST; while several miRNAs directly down- or up-regulate GLAST, GLT-1, and EAAC1. Green arrows represent up-regulation, red arrows indicate down-regulation, and orange arrow denotes inhibition. The illustration of day/night indicates that transporter present a circadian rhythm in 12/12 h light/dark conditions. Numbers in parentheses refer to cited publications. CLOCK, circadian locomotor output cycles kaput; EAAC1, excitatory amino acid carrier 1; GLAST, glutamate aspartate transporter; Gln, glutamine; GLT-1, glutamate transporter 1; Glu, glutamate; NPAS2, neuronal PAS domain-containing protein 2; PER2, period 2; SNATs, sodium-coupled neutral amino acid transporters; VGluT, vesicular glutamate transporter.

\section{AUTHOR CONTRIBUTIONS}

DC-C gathered the relevant information, wrote the manuscript, as well as elaborated the figure. AO revised and edited the final version of the manuscript.

\section{REFERENCES}

1. Halberg F. Physiologic 24-hour periodicity; general and procedural considerations with reference to the adrenal cycle. Int $Z$ Vitaminforsch Beih (1959) 10:225-96.

2. Schibler U, Sassone-Corsi P. A web of circadian pacemakers. Cell (2002) 111:919-22. doi: 10.1016/S0092-8674(02)01225-4

3. Stratmann M, Schibler U. Properties, entrainment, and physiological functions of mammalian peripheral oscillators. J Biol Rhythms (2006) 21:494506. doi: $10.1177 / 0748730406293889$

4. Roenneberg T, Daan S, Merrow M. The art of entrainment. J Biol Rhythms (2003) 18:183-94. doi: 10.1177/0748730403018003001

5. Dunlap JC. Molecular bases for circadian clocks. Cell (1999) 96:271-90. doi: 10.1016/S0092-8674(00)80566-8

6. Harmer SL, Panda S, Kay SA. Molecular bases of circadian rhythms. Annu Rev Cell Dev Biol. (2001) 17:215-53. doi: 10.1146/annurev.cellbio.17.1.215

7. Reppert SM, Weaver DR. Molecular analysis of mammalian circadian rhythms. Annu Rev Physiol. (2001) 63:647-76. doi: 10.1146/annurev.physiol.63.1.647

8. Okamura H, Yamaguchi S, Yagita K. Molecular machinery of the circadian clock in mammals. Cell Tissue Res. (2002) 309:47-56. doi: 10.1007/s00441-002-0572-5

9. Lowrey PL, Takahashi JS. Mammalian circadian biology: elucidating genomewide levels of temporal organization. Annu Rev Genomics Hum Genet. (2004) 5:407-41. doi: 10.1146/annurev.genom.5.061903.175925

\section{FUNDING}

The work in the lab is supported by grant from Conacyt-México to AO (255087). DC-C is supported by SNI-Conacyt.

10. Panda S, Antoch MP, Miller BH, Su AI, Schook AB, Straume M, et al. Coordinated transcription of key pathways in the mouse by the circadian clock. Cell (2002) 109:307-20. doi: 10.1016/S0092-8674(02)00722-5

11. Kornmann B, Schaad O, Bujard H, Takahashi JS, Schibler U. System-driven and oscillator-dependent circadian transcription in mice with a conditionally active liver clock. PLoS Biol. (2007) 5:e34. doi: 10.1371/journal.pbio.0050034

12. Berson DM, Dunn FA, Takao M. Phototransduction by retinal ganglion cells that set the circadian clock. Science (2002) 295:1070-3. doi: $10.1126 /$ science. 1067262

13. Hughes S, Jagannath A, Hankins MW, Foster RG, Peirson SN. Photic regulation of clock systems. Methods Enzymol. (2015) 552:125-43. doi: 10.1016/bs.mie.2014.10.018

14. Ebling FJP. The role of glutamate in the photic regulation of the suprachiasmatic nucleus. Prog Neurobiol. (1996) 50:109-32. doi: 10.1016/S0301-0082(96)00032-9

15. Chen D, Buchanan GF, Ding JM, Hannibal J, Gillette MU. Pituitary adenylyl cyclase-activating peptide: a pivotal modulator of glutamatergic regulation of the suprachiasmatic circadian clock. Proc Natl Acad Sci USA. (1999) 96:13468-73. doi: 10.1073/pnas.96.23.13468

16. Golombek DA, Ferreyra GA, Agostino P V, Murad AD, Rubio MF, Pizzio GA, et al. From light to genes: moving the hands of the circadian clock. Front Biosci. (2003) 8:285-93. doi: 10.2741/1038

17. Piggins HD, Rusak B. Effects of microinjections of substance P into the suprachiasmatic nucleus region on hamster wheel-running rhythms. Brain Res Bull. (1997) 42:451-5. 
18. Hamada T, Yamanouchi S, Watanabe A, Shibata S, Watanabe S. Involvement of glutamate release in substance P-induced phase delays of suprachiasmatic neuron activity rhythm in vitro. Brain Res. (1999) 836:190-3. doi: 10.1016/S0006-8993(99)01565-6

19. Harrington ME, Hoque S, Hall A, Golombek D, Biello S. Pituitary adenylate cyclase activating peptide phase shifts circadian rhythms in a manner similar to light. J Neurosci. (1999) 19:6637-42. doi: 10.1523/JNEUROSCI.19-15-06637.1999

20. Gillette MU. Regulation of entrainment pathways by the suprachiasmatic circadian clock: sensitivities to second messengers. Prog Brain Res. (1996) 111:121-32. doi: 10.1016/S0079-6123(08)60404-5

21. Gooley JJ, Saper CB. Anatomy of the mammalian circadian system. In: Kryger M, Roth T, Dement W, editors Principles and Practice of Sleep Medicine. (Philadelphia, WB: Saunders) (2011), p. 376-89.

22. Brancaccio M, Patton AP, Chesham JE, Maywood ES, Hastings MH. Astrocytes control circadian timekeeping in the suprachiasmatic nucleus via glutamatergic signaling. Neuron (2017) 93:1420-35. doi: 10.1016/j.neuron.2017.02.030

23. Conn PJ, Patel J. The Metabotropic Glutamate Receptors. Totowa, NJ: Humana Press (1994). 277 p.

24. Hollmann M, Heinemann S. Cloned glutamate receptors. Annu Rev Neurosci. (1994) 17:31-108. doi: 10.1146/annurev.ne.17.030194. 000335

25. Coutinho V, Knöpfel T. Metabotropic glutamate receptors: electrical and chemical signaling properties. Neuroscientist (2002) 8:551-61. doi: $10.1177 / 1073858402238514$

26. Schoepp DD, Conn PJ. Metabotropic glutamate receptors in brain function and pathology. Trends Pharmacol Sci. (1993) 14:13-20. doi: 10.1016/0165-6147(93)90107-U

27. Engelman HS, MacDermott AB. Presynaptic ionotropic receptors and control of transmitter release. Nat Rev Neurosci. (2004) 5:135-45. doi: $10.1038 / \mathrm{nrn} 1297$

28. Danbolt NC. Glutamate uptake. Prog Neurobiol. (2001) 65:1-105. doi: 10.1016/S0301-0082(00)00067-8

29. Clements JD, Lester RA, Tong G, Jahr CE, Westbrook GL. The time course of glutamate in the synaptic cleft. Science (1992) 258:1498-501. doi: 10.1126/science. 1359647

30. Domingues AM de J, Taylor M, Fern R. Glia as transmitter sources and sensors in health and disease. Neurochem Int. (2010) 57:359-66. doi: 10.1016/j.neuint.2010.03.024

31. Kanai Y, Hediger MA. Primary structure and functional characterization of a high-affinity glutamate transporter. Nature (1992) 360:467-71. doi: $10.1038 / 360467 \mathrm{a} 0$

32. Pines G, Danbolt NC, Bjørås M, Zhang Y, Bendahan A, Eide L, et al. Cloning and expression of a rat brain L-glutamate transporter. Nature (1992) 360:4647.

33. Storck T, Schulte S, Hofmann K, Stoffel W. Structure, expression, and functional analysis of a $\mathrm{Na}(+)$-dependent glutamate/aspartate transporter from rat brain. Proc Natl Acad Sci USA. (1992) 89:10955-9. doi: 10.1073/pnas.89.22.10955

34. Arriza JL, Fairman WA, Wadiche JI, Murdoch GH, Kavanaugh MP, Amara SG. Functional comparisons of three glutamate transporter subtypes cloned from human motor cortex. J Neurosci. (1994) 14:5559-69. doi: 10.1523/JNEUROSCI.14-09-05559.1994

35. Fairman WA, Vandenberg RJ, Arriza JL, Kavanaugh MP, Amara SG. An excitatory amino-acid transporter with properties of a ligandgated chloride channel. Nature (1995) 375:599-603. doi: 10.1038/375 $599 \mathrm{a} 0$

36. Arriza JL, Eliasof S, Kavanaugh MP, Amara SG. Excitatory amino acid transporter 5, a retinal glutamate transporter coupled to a chloride conductance. Proc Natl Acad Sci USA. (1997) 94:4155-60. doi: 10.1073/pnas.94.8.4155

37. Danbolt NC, Furness DN, Zhou Y. Neuronal vs glial glutamate uptake: resolving the conundrum. Neurochem Int. (2016) 98:29-45. doi: 10.1016/j.neuint.2016.05.009

38. Rothstein JD, Martin L, Levey AI, Dykes-Hoberg M, Jin L, Wu D, et al. Localization of neuronal and glial glutamate transporters. Neuron (1994) 13:713-25.
39. Furuta A, Rothstein JD, Martin LJ. Glutamate transporter protein subtypes are expressed differentially during rat CNS development. J Neurosci. (1997) 17:8363-75. doi: 10.1523/JNEUROSCI.17-21-08363.1997

40. Lehre KP, Danbolt NC. The number of glutamate transporter subtype molecules at glutamatergic synapses: chemical and stereological quantification in young adult rat brain. J Neurosci. (1998) 18:8751-7. doi: 10.1523/JNEUROSCI.18-21-08751.1998

41. Dehnes Y, Chaudhry FA, Ullensvang K, Lehre KP, Storm-Mathisen J, Danbolt NC. The glutamate transporter EAAT4 in rat cerebellar Purkinje cells: a glutamate-gated chloride channel concentrated near the synapse in parts of the dendritic membrane facing astroglia. J Neurosci. (1998) 18:3606-19. doi: 10.1523/JNEUROSCI.18-10-03606.1998

42. Chen W, Mahadomrongkul V, Berger UV, Bassan M, DeSilva T, Tanaka $\mathrm{K}$, et al. The glutamate transporter GLT-1a is expressed in excitatory axon terminals of mature hippocampal neurons. J Neusrosci. (2004) 24:113648. doi: 10.1523/JNEUROSCI.1586-03.2004

43. Furness DN, Dehnes Y, Akhtar AQ, Rossi DJ, Hamann M, Grutle NJ, et al. A quantitative assessment of glutamate uptake into hippocampal synaptic terminals and astrocytes: new insights into a neuronal role for excitatory amino acid transporter 2 (EAAT2). Neuroscience (2008) 157:80-94. doi: 10.1016/j.neuroscience.2008.08.043

44. Melone M, Bellesi M, Conti F. Synaptic localization of GLT-1 in the rat somatic sensory cortex. Glia (2009) 57:108-17. doi: 10.1002/glia.20744

45. Conti F, DeBiasi S, Minelli A, Rothstein JD, Melone M. EAAC1, a high-affinity glutamate tranporter, is localized to astrocytes and gabaergic neurons besides pyramidal cells in the rat cerebral cortex. Cereb Cortex (1998) 8:108-16. doi: $10.1093 /$ cercor/8.2.108

46. Hu WH, Walters WM, Xia XM, Karmally SA, Bethea JR. Neuronal glutamate transporter EAAT4 is expressed in astrocytes. Glia (2003) 44:13-25. doi: $10.1002 /$ glia.10268

47. Rothstein JD, Dykes-Hoberg M, Pardo CA, Bristol LA, Jin L, Kuncl RW, et al. Knockout of glutamate transporters reveals a major role for astroglial transport in excitotoxicity and clearance of glutamate. Neuron (1996) 16:67586.

48. Tanaka K, Watase K, Manabe T, Yamada K, Watanabe M, Takahashi K, et al. Epilepsy and exacerbation of brain injury in mice lacking the glutamate transporter GLT-1. Science (1997) 276:1699-702.

49. Sheldon AL, Robinson $\mathrm{MB}$. The role of glutamate transporters in neurodegenerative diseases and potential opportunities for intervention. Neurochem Int. (2007) 51:333-55. doi: 10.1016/j.neuint.2007.03.012

50. Ferrarese C, Begni B, Canevari C, Zoia C, Piolti R, Frigo $\mathrm{M}$, et al. Glutamate uptake is decreased in platelets from Alzheimer's disease patients. Ann Neurol. (2000) 47:641-3. doi: 10.1002/1531-8249(200005)47:5<641::AID-ANA12>3.0.CO;2-I

51. Masliah E, Alford M, Mallory M, Rockenstein E, Moechars D, Van Leuven F. Abnormal glutamate transport function in mutant amyloid precursor protein transgenic mice. Exp Neurol. (2000) 163:381-7. doi: 10.1006/exnr.2000.7386

52. Zoia CP, Tagliabue E, Isella V, Begni B, Fumagalli L, Brighina L, et al. Fibroblast glutamate transport in aging and in $\mathrm{AD}$ : correlations with disease severity. Neurobiol Aging (2005) 26:825-32. doi: 10.1016/j.neurobiolaging.2004.07.007

53. Woltjer RL, Duerson K, Fullmer JM, Mookherjee P, Ryan AM, Montine TJ, et al. Aberrant detergent-insoluble excitatory amino acid transporter 2 accumulates in Alzheimer disease. J Neuropathol Exp Neurol. (2010) 69:667-76. doi: 10.1097/NEN.0b013e3181e24adb

54. Takahashi K, Kong Q, Lin Y, Stouffer N, Schulte DA, Lai L, et al. Restored glial glutamate transporter EAAT2 function as a potential therapeutic approach for Alzheimer's disease. J Exp Med. (2015) 212:319-32. doi: 10.1084/jem.20140413

55. Scott HA, Gebhardt FM, Mitrovic AD, Vandenberg RJ, Dodd PR. Glutamate transporter variants reduce glutamate uptake in Alzheimer's disease. Neurobiol Aging (2011) 32:553.e1-11. doi: 10.1016/j.neurobiolaging.2010.03.008

56. Scott HL, Pow D V, Tannenberg AEG, Dodd PR. Aberrant expression of the glutamate transporter excitatory amino acid transporter 1 (EAAT1) in Alzheimer's disease. J Neurosci. (2002) 22:RC206. doi: 10.1523/JNEUROSCI.22-03-j0004.2002

57. Thai DR. Excitatory amino acid transporter EAAT-2 in tangle-bearing neurons in Alzheimer's disease. Brain Pathol. (2002) 12:405-11. doi: 10.1111/j.1750-3639.2002.tb00457.x 
58. Zhang $\mathrm{Y}$, He X, Meng X, Wu X, Tong H, Zhang X, et al. Regulation of glutamate transporter trafficking by Nedd4-2 in a Parkinson's disease model. Cell Death Dis. (2017) 8:e2574. doi: 10.1038/cddis.2016.454

59. Estrada-Sánchez AM, Rebec G V. Corticostriatal dysfunction and glutamate transporter 1 (GLT1) in Huntington's disease: interactions between neurons and astrocytes. Basal Ganglia (2012) 2:57-66. doi: 10.1016/j.baga.2012.04.029

60. Hassel B, Tessler S, Faull RLM, Emson PC. Glutamate uptake is reduced in prefrontal cortex in Huntington's disease. Neurochem Res (2008) 33:232-7. doi: 10.1007/s11064-007-9463-1

61. Robinson MB. Regulated trafficking of neurotransmitter transporters: common notes but different melodies. J Neurochem. (2002) 80:1-11. doi: 10.1046/j.0022-3042.2001.00698.x

62. Shin JW, Nguyen KTD, Pow D V, Knight T, Buljan V, Bennett MR, et al. Distribution of Glutamate Transporter GLAST in membranes of cultured astrocytes in the presence of glutamate transport substrates and ATP. Neurochem Res. (2009) 34:1758-66. doi: 10.1007/s11064-009-9982-z

63. Benediktsson AM, Marrs GS, Tu JC, Worley PF, Rothstein JD, Bergles DE, et al. Neuronal activity regulates glutamate transporter dynamics in developing astrocytes. Glia (2012) 60:175-88. doi: 10.1002/glia.21249

64. Murphy-Royal C, Dupuis JP, Varela JA, Panatier A, Pinson B, Baufreton J, et al. Surface diffusion of astrocytic glutamate transporters shapes synaptic transmission. Nat Neurosci. (2015) 18:219-26. doi: 10.1038/nn.3901

65. Spanagel R, Pendyala G, Abarca C, Zghoul T, Sanchis-Segura C, Magnone MC, et al. The clock gene Per2 influences the glutamatergic system and modulates alcohol consumption. Nat Med. (2005) 11:35-42. doi: 10.1038/nm1163

66. Beaulé C, Swanstrom A, Leone MJ, Herzog ED. Circadian modulation of gene expression, but not glutamate uptake, in mouse and rat cortical astrocytes. PLoS ONE (2009) 4:e7476. doi: 10.1371/journal.pone.0007476

67. Beaulé C, Granados-Fuentes D, Marpegan L, Herzog ED. In vitro circadian rhythms: imaging and electrophysiology. Essays Biochem. (2011) 49:103-17. doi: 10.1042/BSE0490103

68. Leone MJ, Beaule C, Marpegan L, Simon T, Herzog ED, Golombek DA. Glial and light-dependent glutamate metabolism in the suprachiasmatic nuclei. Chronobiol Int. (2015) 32:573-8. doi: 10.3109/07420528.2015.1006328

69. Cagampang FR, Rattray M, Powell JF, Campbell IC, Coen CW. Circadian changes of glutamate decarboxylase 65 and 67 mRNA in the rat suprachiasmatic nuclei. Neuroreport (1996) 7:1925-8. doi: 10.1097/00001756-199608120-00011

70. Abrahamson EE, Moore RY. Suprachiasmatic nucleus in the mouse: retinal innervation, intrinsic organization and efferent projections. Brain Res. (2001) 916:172-91. doi: 10.1016/S0006-8993(01)02890-6

71. Kinoshita C, Aoyama K, Matsumura N, Kikuchi-Utsumi K, Watabe M, Nakaki T. Rhythmic oscillations of the microRNA miR-96-5p play a neuroprotective role by indirectly regulating glutathione levels. Nat Commun. (2014) 5:1-10. doi: $10.1038 /$ ncomms 4823

72. Cheng HYM, Papp JW, Varlamova O, Dziema H, Russell B, Curfman JP, et al. microRNA modulation of circadian-clock period and entrainment. Neuron (2007) 54:813-29. doi: 10.1016/j.neuron.2007.05.017

73. Weigl Y, Ashkenazi IE, Peleg L. Rhythmic profiles of cell cycle and circadian clock gene transcripts in mice: a possible association between two periodic systems. J Exp Biol. (2013) 216:2276-82. doi: 10.1242/jeb.081729

74. Heegaard NHH, Carlsen AL, Lilje B, Ng KL, Rønne ME, Jørgensen HL, et al. Diurnal variations of human circulating cell-free micro-RNA. PLOS ONE (2016) 11:e0160577. doi: 10.1371/journal.pone.0160577
75. Wang H, Fan Z, Zhao M, Li J, Lu M, Liu W, et al. Oscillating primary transcripts harbor miRNAs with circadian functions. Sci Rep. (2016) 6:21598. doi: $10.1038 /$ srep 21598

76. Yang M, Lee JE, Padgett RW, Edery I. Circadian regulation of a limited set of conserved microRNAs in Drosophila. BMC Genomics (2008) 9:83. doi: 10.1186/1471-2164-9-83

77. Daimiel-Ruiz L, Klett-Mingo M, Konstantinidou V, Micó V, Aranda JF, García B, et al. Dietary lipids modulate the expression of miR-107, a miRNA that regulates the circadian system. Mol Nutr Food Res. (2015) 59:1865-78. doi: $10.1002 / \mathrm{mnfr} .201400616$

78. Figueredo D de S, Gitaí DLG, Andrade TG de. Daily variations in the expression of miR-16 and miR-181a in human leukocytes. Blood Cells Mol Dis. (2015) 54:364-8. doi: 10.1016/j.bcmd.2015.01.004

79. Lee HS, Ghetti A, Pinto-Duarte A, Wang X, Dziewczapolski G, Galimi F, et al. Astrocytes contribute to gamma oscillations and recognition memory. Proc Natl Acad Sci USA. (2014) 111:E3343-52. doi: 10.1073/pnas.1410893111

80. Gao W, Bi Y, Ding L, Zhu W, Ye M. SSa ameliorates the Glu uptaking capacity of astrocytes in epilepsy via AP-1/miR-155/GLAST. Biochem Biophys Res Commun. (2017) 493:1329-35. doi: 10.1016/j.bbrc.2017.09.139

81. Mandolesi G, De Vito F, Musella A, Gentile A, Bullitta S, Fresegna $\mathrm{D}$, et al. miR-142-3p is a key regulator of IL-1 $\beta$-dependent synaptopathy in neuroinflammation. J Neurosci (2017) 37:546-61. doi: 10.1523/JNEUROSCI.0851-16.2016

82. Moon J, Xu L, Giffard RG. Inhibition of microRNA-181 reduces forebrain ischemia-induced neuronal loss. J Cereb Blood Flow Metab. (2013) 33:197682. doi: $10.1038 / \mathrm{jcbfm} .2013 .157$

83. Lee HK, Finniss S, Cazacu S, Xiang C, Brodie C. Mesenchymal stem cells deliver exogenous miRNAs to neural cells and induce their differentiation and glutamate transporter expression. Stem Cells Dev. (2014) 23:2851-61. doi: $10.1089 / \mathrm{scd} .2014 .0146$

84. Yang ZB, Zhang Z, Li T-B, Lou Z, Li SY, Yang H, et al. Up-regulation of brain-enriched miR-107 promotes excitatory neurotoxicity through downregulation of glutamate transporter-1 expression following ischaemic stroke. Clin Sci. (2014) 127:679-89. doi: 10.1042/CS20140084

85. Potenza N, Mosca N, Mondola P, Damiano S, Russo A, De Felice B. Human miR-26a-5p regulates the glutamate transporter SLC1A1 (EAAT3) expression. Relevance in multiple sclerosis. Biochim Biophys Acta Mol Basis Dis. (2018) 1864:317-23. doi: 10.1016/j.bbadis.2017.09.024

86. Wei Y Bin, Melas PA, Villaescusa JC, Liu JJ, Xu N, Christiansen SH, et al. MicroRNA 101b is downregulated in the prefrontal cortex of a genetic model of depression and targets the glutamate transporter SLC1A1 (EAAT3) in vitro. Int J Neuropsychopharmacol (2016) 19:pyw069. doi: 10.1093/ijnp/pyw069

Conflict of Interest Statement: The authors declare that the research was conducted in the absence of any commercial or financial relationships that could be construed as a potential conflict of interest.

Copyright () 2018 Chi-Castañeda and Ortega. This is an open-access article distributed under the terms of the Creative Commons Attribution License (CC BY). The use, distribution or reproduction in other forums is permitted, provided the original author(s) and the copyright owner(s) are credited and that the original publication in this journal is cited, in accordance with accepted academic practice. No use, distribution or reproduction is permitted which does not comply with these terms. 